\title{
VERTICAL ACCURACY ASSESSMENT OF THE PROCESSED SRTM DATA FOR THE BRAZILIAN TERRITORY
}

\author{
Alex Gois Orlandi ${ }^{1}$ - ORCID 0000-0003-3303-2642 \\ Osmar Abílio de Carvalho Júnior ${ }^{1}$ - ORCID 0000-0002-0346-1684 \\ Renato Fontes Guimarães ${ }^{1}$ - ORCID 0000-0002-9555-043X \\ Edilson de Souza Bias ${ }^{2}$ - ORCID 0000-0003-0334-0476 \\ Douglas Corbari Corrêa ${ }^{3}$ - ORCID 0000-0001-5288-4061 \\ Roberto Arnaldo Trancoso Gomes ${ }^{1}$ - ORCID 0000-0003-4724-4064
}

${ }^{1}$ Universidade Federal de Brasília, Instituto de Humanas, Departamento de Geografia, Brasília, Distrito Federal, Brasil. E-mail: alexgoisorlandi@gmail.com, osmarjr@unb.br, renatofg@unb.br, robertogomes@unb.br

${ }^{2}$ Universidade Federal de Brasília, Instituto de Geociências, Brasília, Distrito Federal, Brasil. E-mail: edbias@unb.br

${ }^{3}$ Gabinete do Comando do Exército - Bloco A - 4o Piso - SMU, Brasília, Distrito Federal, Brasil. E-mail: douglascorbari@gmail.com

Received in $19^{\text {th }}$ June 2018

Accepted in $31^{\text {st }}$ May 2019

\begin{abstract}
:
This research aims to determine the vertical accuracy of the Interferometric Digital Elevation Model (DEM) obtained from the processed Shuttle Radar Topographic Mission (SRTM) data. The research compared the SRTM-GL1 (Shuttle Radar Topographic Mission-Global 1) with 30-meter resolution and the following 90-meter resolution models: (a) EMBRAPA; (b) Hydrological data and maps based on Shuttle Elevation Derivatives at multiple Scales (HydroSHEDS) (HydroSHEDS), provided by the United States Geological Survey (USGS); (c) Consultative Group for International Agricultural Research-Consortium for Spatial Information (CGIAR-CSI); and (d) Jonathan de Ferranti. The accuracy analysis considered the diverse Brazilian regions, adopting 1,087 field points from the Global Navigation Satellite System (GNSS) trackers or topography methods. The Jonathan de Ferranti model achieved the best accuracy with RMSE of $9.61 \mathrm{~m}$ among the 90 -meter resolution models. Most SRTM models at 1:100,000 scale reached Grade A of the Cartographic Accuracy Standard. However, the accuracy at the 1: 50,000 scale did not achieve the same performance. SRTM errors are linearly related to slope and the most significant errors always occur in forest areas. The 30-meter resolution SRTM showed an accuracy of around 10\% better (RMSE of $8.52 \mathrm{~m}$ ) than the model of Jonathan de Ferranti with 90-meter resolution (RMSE of 9.61m).
\end{abstract}

Keywords: SRTM mission, vertical accuracy, interferometry, digital elevation model.

How to cite this article: ORLANDI, A. G.; CARVALHO-JÚNIOR, O. A.; GUIMARÃES, R. F.; BIAS, E. S.; CORRÊA, D. C.; GOMES, R. A. T. Vertical accuracy assessment of the processed SRTM data for the brazilian territory. Bulletin of Geodetic Sciences. 25(4): e2019021, 2019. 


\section{Introduction}

The Shuttle Radar Topography Mission (SRTM) is one of the most widely used altimetric data sources in the world, due to its quality and global coverage (Reuter et al. 2007). The SRTM mission, developed by the National Aeronautics and Space and Administration (NASA) and National Geospatial-Intelligence Agency (NGA), obtained topographic data on $80 \%$ of the Earth's surface between parallels $60^{\circ} \mathrm{N}$ and $56^{\circ} \mathrm{S}$ during 11 days (Lehner et al. 2006). The SRTM data has spatial resolutions of $90 \mathrm{~m}$ or $30 \mathrm{~m}$, but the latter was only available from the end of September 2014 (Brochado 2015) and is not the object of this study. The 90-meter SRTM is superior to the Global 30 Arc-Second Elevation (GTOPO30) model, previously available at 1-km resolution (Azizian et al. 2015). Several institutions have processed SRTM data with the purpose of improving their quality, such as National Center for Satellite Monitoring Research of the Brazilian Company of Agricultural Research (EMBRAPA) (Miranda 2005) and TOPODATA data provided by the National Institute for Space Research (INPE) (Valeriano 2008). The free availability of processed SRTM data by government agencies expands its use (Bias et al. 2010; lorio et al. 2012). Therefore, SRTM data has been used in different applications such as flood areas (e.g., Suwandana et al. 2012), glacier inventories (e.g., Frey and Paul 2012), karst depression detection (e.g., Siart et al. 2009; de Carvalho Júnior et al. 2014), and geomorphological mapping (e.g., Vasconcelos et al. 2014; Sena-Souza et al. 2016), among others.

Several scientific studies have evaluated the SRTM accuracies in several regions of the world, using different methods such as topographic measurements, GNSS tracking, and cartographic bases (e.g., 1:10,000 or 1:25,000) obtained by photogrammetric, laser or satellite data (Figure 1 and Table 1). However, most of the SRTM mission data accuracy assessments considered small regions, with few works at a global or regional scale. Besides, few papers compare the models provided by research institutions. Therefore, the primary motivation of this research is the lack of comparative studies on the accuracy of the various models of digital terrain based on the SRTM data considering the extension of the Brazilian territory.

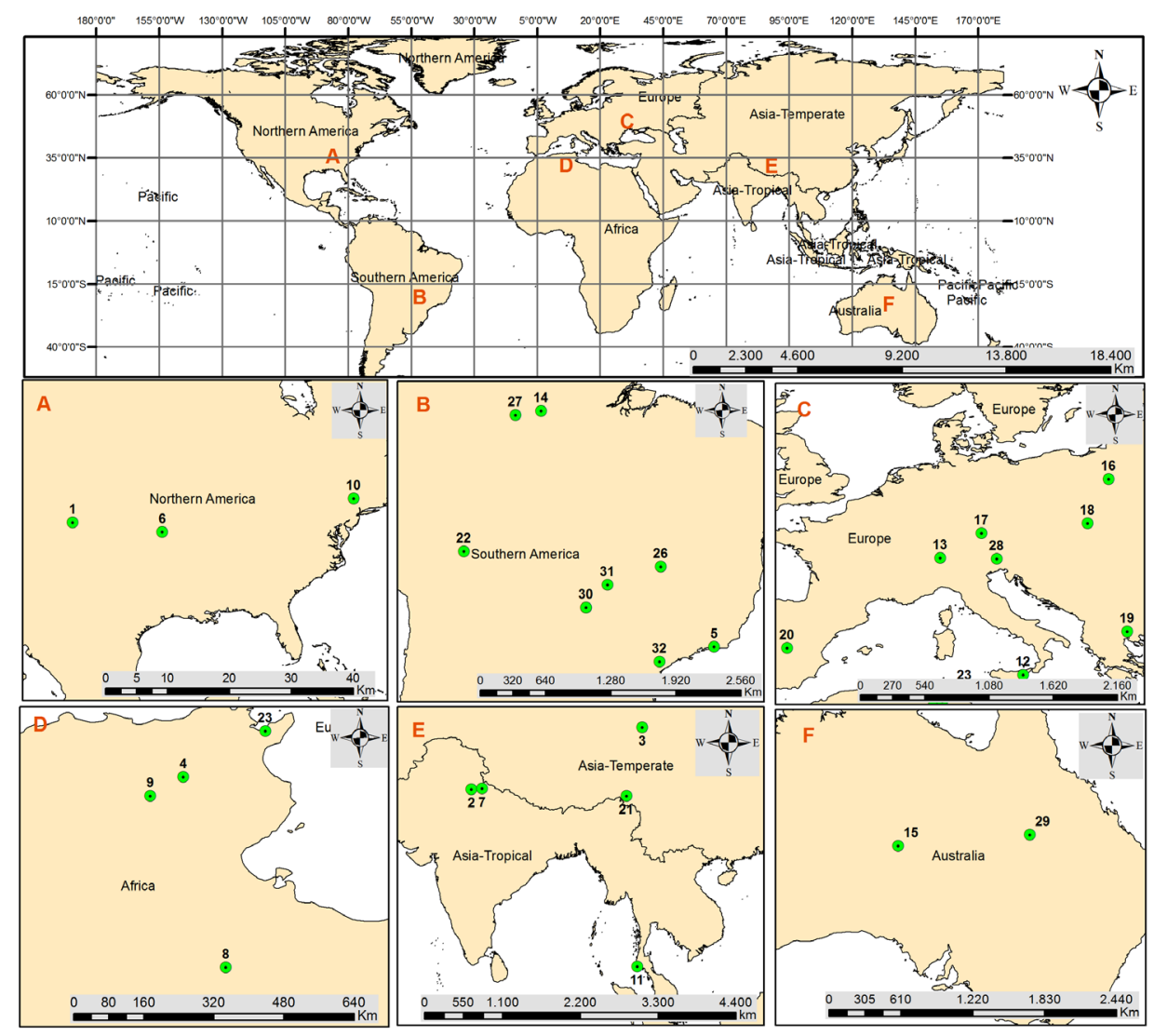

Figure 1: Study sites on SRTM accuracy. $\odot-$ location of the studies described in Table 1. 
The present article aims to identify and compare the vertical accuracy of the SRTM model from different sources for the Brazilian territory according to the National Standard for Cartographic Accuracy (Padrão de Exatidão Cartográfica - PEC) described in Decree 89.817/84, which establishes the general norms of Brazilian cartography (Brasil 1984). Specifically, the research intends: (1) adoption of 1,087 field measurements distributed in Brazil to obtain a spatial representation of the altimetric accuracy; (2) comparison of different treated SRTM data; (3) PEC classification considering a spatial distribution by four degrees of latitude; and (4) evaluation of the slope and vegetation influence in model accuracy.

Table 1: Summary of SRTM data accuracy studies in Figure 1. SD - standard deviation, ME - mean error, and RMSE - root-mean-square error.

\begin{tabular}{|c|c|c|c|c|c|}
\hline & Referência & Local & Modelo & Insumo & Resultados \\
\hline 0 & Berry et al. (2007). & Global & SRTM V2 & Satélite ERS-1. & $\begin{array}{l}\text { ME: } 3.60 \mathrm{~m} ; \\
\text { SD: } 16.16 \mathrm{~m} .\end{array}$ \\
\hline 1 & Shortridge and Messina (2011). & EUA & SRTM-V2 & $\begin{array}{c}\text { National } \\
\text { Elevation } \\
\text { Dataset (NED) } \\
\end{array}$ & $\begin{array}{l}\text { ME: } 2.0 \mathrm{~m} ; \\
\text { SD: } 8.3 \mathrm{~m} .\end{array}$ \\
\hline 2 & Mukherjee et al. (2013). & $\begin{array}{l}\text { Shiwalik } \\
\text { Himalaya }\end{array}$ & $\begin{array}{c}\text { CGIAR-CSI SRTM } \\
\text { v4.1 }\end{array}$ & $\begin{array}{c}\text { Ground Control } \\
\text { Points (GCPs) }\end{array}$ & $\begin{array}{l}\text { ME: }-2.94 \mathrm{~m} \\
\text { RMSE: } 9.20 \mathrm{~m} .\end{array}$ \\
\hline 3 & Liu (2008). & China & NASA SRTM3 & $\begin{array}{c}\text { Topographic map } \\
1: 25.000 \\
\end{array}$ & $\begin{array}{c}\text { ME: }-6.635 \mathrm{~m} ; \mathrm{SD}: \\
29.16 \mathrm{~m} .\end{array}$ \\
\hline 4 & Chaieb et al. (2016) & $\begin{array}{l}\text { Kasserini, } \\
\text { Tunisia }\end{array}$ & SRTM v4.1 & $\begin{array}{c}\text { Ground Control } \\
\text { Points (GCPs) }\end{array}$ & $\begin{array}{l}\text { ME: }-1.85 \mathrm{~m} ; \\
\text { SD: } 9.41 \mathrm{~m} .\end{array}$ \\
\hline 5 & Miceli et al. (2011). & $\begin{array}{c}\text { Rio de janeiro, } \\
\text { Brazil }\end{array}$ & SRTM 1 & $\begin{array}{c}\text { Topographic map } \\
1: 10.000 .\end{array}$ & $\begin{array}{c}90 \% \text { less than } 15 \mathrm{~m} ; \\
\text { RMSE de } 8.86 \mathrm{~m} \text {. }\end{array}$ \\
\hline 6 & Robinson et al. (2014). & EUA & $\begin{array}{c}\text { CGIAR-CSI SRTM } \\
\text { v4.1 }\end{array}$ & $\begin{array}{c}\text { Ground Control } \\
\text { Points (GCPs) }\end{array}$ & $\begin{array}{c}\text { ME: } 1.66 \mathrm{~m} ; \mathrm{RMSE} \\
4.15 \mathrm{~m} .\end{array}$ \\
\hline 7 & Datta and Kirchner (2010) & India & $\begin{array}{l}\text { SRTM University } \\
\text { of Maryland. }\end{array}$ & $\begin{array}{c}\text { Ground Control } \\
\text { Points (GCPs) }\end{array}$ & $\begin{array}{l}\text { ME: }-12.56 \mathrm{~m} ; \\
\text { SD: } 51.37 \mathrm{~m} \text {. }\end{array}$ \\
\hline 8 & Athmania and Achour (2014). & $\begin{array}{l}\text { Anaguid, } \\
\text { Tunisia }\end{array}$ & $\begin{array}{c}\text { CGIAR-CSI SRTM } \\
\text { v4.1 }\end{array}$ & RTK-DGPS & $\begin{array}{l}\text { ME: } 2.9 \mathrm{~m} ; \\
\text { SD: } 4.6 \mathrm{~m} .\end{array}$ \\
\hline 9 & Athmania and Achour (2014). & Tebessa, Tunisia & $\begin{array}{c}\text { CGIAR-CSI SRTM } \\
\text { v4.1 }\end{array}$ & RTK-DGPS & $\begin{array}{l}\text { ME: } 0.48 \mathrm{~m} ; \\
\text { SD: } 8.4 \mathrm{~m} .\end{array}$ \\
\hline 10 & Gorokhovich and Voustianiouck (2006). & $\begin{array}{c}\text { Catskill } \\
\text { Mountains, EUA }\end{array}$ & CGIAR-CSI SRTM & $\begin{array}{c}\text { Ground Control } \\
\text { Points (GCPs) }\end{array}$ & $\begin{array}{l}\text { ME: } 7.58 \mathrm{~m} ; \\
\text { SD: } 8.09 \mathrm{~m} .\end{array}$ \\
\hline 11 & Gorokhovich and Voustianiouck (2006). & $\begin{array}{l}\text { Phuket, } \\
\text { Thailand. }\end{array}$ & CGIAR-CSI SRTM & $\begin{array}{c}\text { Ground Control } \\
\text { Points (GCPs) }\end{array}$ & $\begin{array}{l}\text { ME: } 4.07 \mathrm{~m} ; \\
\text { SD: } 4.01 \mathrm{~m} .\end{array}$ \\
\hline 12 & Tarquini et al. (2012). & Italy & SRTM-JPL-NASA & LIDAR & RMSE: $7.78 \mathrm{~m}$ \\
\hline 13 & Frey and Paul (2012). & Switzerland & SRTM3 & $\begin{array}{c}\text { DHM25 } \\
\text { (swisstopo). }\end{array}$ & $\begin{array}{l}\text { ME: } 2.23 \mathrm{~m} ; \\
\text { SD: } 21.64 \mathrm{~m} .\end{array}$ \\
\hline 14 & Miceli et al. (2011). & Amazon, Brazil & SRTM 1 & $\begin{array}{l}\text { Ground Control } \\
\text { Points (GCPs) }\end{array}$ & $\begin{array}{c}90 \% \text { less than } \\
\text { 25.00m; RMSE: } \\
11.70 \mathrm{~m} .\end{array}$ \\
\hline 15 & Rexer and Hirt (2014) & Australia & $\begin{array}{c}\text { CGIAR-CSI SRTM } \\
\text { v4.1 }\end{array}$ & $\begin{array}{c}\text { Ground Control } \\
\text { Points (GCPs) }\end{array}$ & $\begin{array}{l}\text { ME: } 3.04 \mathrm{~m} ; \\
\text { SD: } 3.22 \mathrm{~m} .\end{array}$ \\
\hline 16 & Karwel and Ewiak (2008) & Poland & SRTM & $\begin{array}{l}\text { Ground Control } \\
\text { Points (GCPs) }\end{array}$ & $\begin{array}{c}\text { RMSE: } 2.9 \mathrm{~m} \text { (plan); } \\
\text { RMSE }=5.4 \mathrm{~m} \\
\text { (mountain) }\end{array}$ \\
\hline 17 & Jörn and Diana (2008) & $\begin{array}{l}\text { Southern } \\
\text { Germany }\end{array}$ & SRTM-JPL-NGA & $\begin{array}{l}\text { Ground Control } \\
\text { Points (GCPs) }\end{array}$ & SD: $3.90 \mathrm{~m}$. \\
\hline
\end{tabular}


Table 1: Continuation.

\begin{tabular}{|c|c|c|c|c|c|}
\hline & Referência & Local & Modelo & Insumo & Resultados \\
\hline 18 & Natalia and Jacek (2014) & Poland & SRTM -v4 & $\begin{array}{c}\text { DEM- } \\
\text { Cartographic } \\
\text { Inventory }\end{array}$ & $\begin{array}{c}\mathrm{ME}: 4.31 \mathrm{~m} ; \mathrm{SD}: \\
14.09 \mathrm{~m} .\end{array}$ \\
\hline 19 & Antonios et al. (2010) & Greece & SRTM v4 & $\begin{array}{l}\text { KGPS coletados } \\
\text { com veículo } \\
\text { (GPS). }\end{array}$ & $\begin{array}{c}\mathrm{ME}: 0.30 \mathrm{~m} ; \mathrm{SD}: \\
6.40 \mathrm{~m} .\end{array}$ \\
\hline 20 & Alvaro et al. (2011) & Spain & SRTM v4.1 & $\begin{array}{c}\text { Topographic map } \\
1: 10.000 \\
\end{array}$ & RMSE: $6.10 \mathrm{~m}$ \\
\hline 21 & Wang et al. (2012) & Tibet & CIGIAR_SRTM & $\begin{array}{c}\text { Topographic map } \\
1: 50.000\end{array}$ & $\begin{array}{c}\text { ME: } 5.3 \mathrm{~m} \text {; SD: } \\
12.2 \mathrm{~m} .\end{array}$ \\
\hline 22 & Mukul et al. (2015) & South America & SRTM v4.1 & $\begin{array}{c}\text { Ground Control } \\
\text { Points (GCPs) }\end{array}$ & $\begin{array}{c}\text { ME: } 5.2 \mathrm{~m} ; \\
\text { RMSE:11.2m. }\end{array}$ \\
\hline 23 & Ouerghi et al. (2015) & $\begin{array}{c}\text { Grombalia, } \\
\text { Tunisia }\end{array}$ & SRTM v4.1 & $\begin{array}{c}\text { Topographic map } \\
1: 25.000\end{array}$ & $\begin{array}{c}\text { ME: } 0.76 \mathrm{~m} ; \mathrm{SD}: \\
47.46 \mathrm{~m} .\end{array}$ \\
\hline 24 & Suwandana et al. (2012). & Indonesia & SRTM v4.1 & RTK-DGPS & RMSE: $3.250 \mathrm{~m}$ \\
\hline 25 & Mukul et al. (2015) & Global & SRTM v4.1 & $\begin{array}{c}\text { Ground Control } \\
\text { Points (GCPs) }\end{array}$ & $\begin{array}{c}\text { ME: } 8.0 \mathrm{~m} \text {; SD: } \\
8.3 \mathrm{~m} .\end{array}$ \\
\hline 26 & Moura et al. (2014) & $\begin{array}{c}\text { Federal District, } \\
\text { Brazil }\end{array}$ & SRTM v4 & $\begin{array}{c}\text { Topographic map } \\
1: 10.000 \\
\end{array}$ & $\begin{array}{c}\text { ME: } 3.14 \mathrm{~m} ; \mathrm{SD}: \\
4.06 \mathrm{~m} .\end{array}$ \\
\hline 27 & Santos et al. (2006) & Amazon, Brazil & SRTM-3 & $\begin{array}{c}\text { Ground Control } \\
\text { Points (GCPs) }\end{array}$ & SD: $11.06 \mathrm{~m}$. \\
\hline 28 & Ludwig and Schneider (2006) & Germany & SRTM & $\begin{array}{c}\text { Topographic map } \\
1: 25.000 \\
\end{array}$ & $\begin{array}{c}\text { ME: } 11.98 \mathrm{~m} ; \\
\text { RMSE: } 36.21 \mathrm{~m} \text {. }\end{array}$ \\
\hline 29 & Jarihani et al. (2015) & Australia & SRTM (30/90m) & $\begin{array}{c}\text { Ground Control } \\
\text { Points (GCPs) }\end{array}$ & SD: $1.84 \mathrm{~m}$ \\
\hline 30 & lorio et al. (2011) & Pantanal, Brazil & SRTM v4 & $\begin{array}{l}\text { Ground Control } \\
\text { Points (GCPs) }\end{array}$ & RMSE: $16.69 \mathrm{~m}$ \\
\hline 31 & Medeiros et al. (2009) & Goiás, Brazil & SRTM-EMBRAPA & $\begin{array}{c}\text { Ground Control } \\
\text { Points (GCPs) }\end{array}$ & $\begin{array}{l}\text { ME: }-3.0 \mathrm{~m} ; \\
\text { SD:10.0m. }\end{array}$ \\
\hline 32 & Nobrega et al. (2005) & São Paulo Brazil & SRTM & $\begin{array}{c}\text { Photogrammetry } \\
1: 8.000\end{array}$ & $\begin{array}{l}\text { ME: } 14.23 \mathrm{~m} ; \\
\text { SD:13.73m. }\end{array}$ \\
\hline
\end{tabular}

\section{Materials and Methods}

\subsection{Acquisition and Distribution of Field Data}

The Brazilian territory was divided into intervals of four-degree latitudes to obtain a homogeneous distribution of the field data and to minimize the occurrence of vast areas without data, making it similar to the division achieved in the Brazilian systematic mapping at 1:1,000,000 scale (IBGE 2016). The selection included the maximum UTM zones that cover the Brazilian territory: 20, 21, 22, 23 and 24 (Figure 2). The selected regions sought to include different levels of altitudes. The highest measured point was in the height of 829.09 meters and the lowest at the elevation of 0.74 meters.

The data used were obtained from the Documentation Center of the Brazilian Electricity Regulatory Agency (ANEEL), where the projects of hydroelectric plants or hydroelectric inventories approved are archived (ANEEL 2009). 
The measured points in the field came from GNSS (Global Navigation Satellite System) trackers to support photogrammetric restitutions or topographic survey. The data selection considered zones with 4 degrees of latitude for Brazil. The field points were converted to a single reference system, SIRGAS2000. The SRTM evaluation adopted at least 50 field points for each latitude zone.

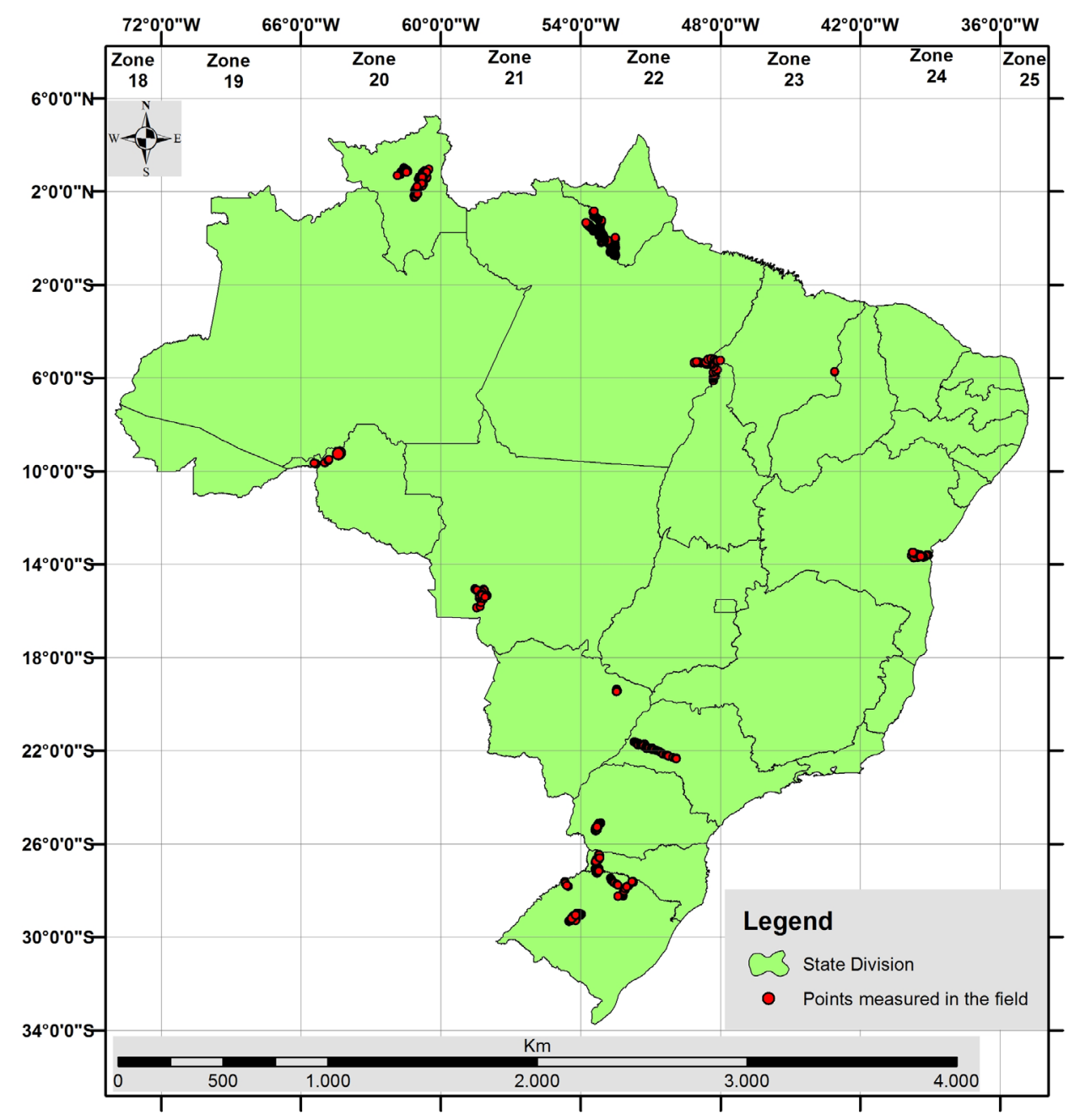

Figure 2: Division of Brazil in zones with 4 degrees of latitude (SIRGAS2000, UTM), containing location of the points measured in the field.

\subsection{Digital Elevation Models Evaluated and Data Processing}

The present research used the SRTM-GL1 with 30-meter resolution and the following processed SRTM models with 90-meter resolution: (a) EMBRAPA (Miranda 2005); (b) Shuttle Elevation Derivatives at multiple Scales (HydroSHEDS) (Lehner et al. 2006); (c) Consultative Group for International Agricultural Research-Consortium for Spatial Information (CGIAR-CSI) version 4.1 (CGIAR-CSI 2016); and (d) Jonathan de Ferranti (Ferranti 2016). The SRTM from the National Center for Satellite Monitoring Research of EMBRAPA has a GeoTIFF format that covers an area of 10 (latitude) by 1030 '(longitude), containing correction of spurious depressions, anomalous peaks and lack of data. The HydroSHEDS model is a hydrologically conditioned DEM, providing data such as drainage lines, river basin boundaries, and stream topology (Lehner et al. 2006; Dasgupta 2011; Lehner 2012). HydroSHEDS data is available in raster format in grids of $5 \times 5$ degree. The CGIAR-CSI Model (version 4.1) is available in GeoTIFF format in 
regions with equal grid size ( $5 \times 5$ degrees), having a void-filling procedure and applications for the slope calculation, flood modeling and obtaining elevations of mountains (Wang et al. 2012; Kolecka and Kozak 2014; Rexer and Hirt 2014). The Jonathan de Ferranti model is available in the HGT file, containing $1 \times 1$ degree data titles and void filling mainly in mountainous regions (Tait 2010). The SRTM-GL1 at a global scale is available in the HGT file (1x1 degree grid), comprising an improved spatial resolution of 30 meters (NASA JPL 2013; Watkins 2018).

The different SRTM models were reprojected for the same SIRGAS2000 Reference System. A Triangulated Irregular Network (TIN) was generated from the SRTM model (raster format) to calculate the altitude of the measured in the field. The option by the TIN method was its suitability to represent altimetry variations (Fernandes and Menezes 2005). With the two orthometric altitudes, the error is the simple difference between the SRTM and the respective field values and the root mean squared error (RMSE) is the standard deviation of the errors.

The RMSEs of the SRTM models are compared with the tabulated values of the PEC to establish the accuracy class. The PEC (Decree $\mathrm{n} 0$ 89.817/1984; Brazil 1984) establishes three accuracy classes according to the scale of the map: " $A$ ", " $B$ ", and " $C$ "; where " $A$ " is the most accurate product. Table 2 lists the PEC classification for the 1: 50,000 and 1: 100,000 scales. This approach enables a comparison with other studies (Santos et al. 2006; Miceli et al. 2011).

Besides, we evaluated the elevation errors from slope and vegetation type, considering the best SRTM model $(90 \mathrm{~m})$ among the four tested. The slope analysis considered the mean absolute error within the following slope intervals $(<1 \%, 1-5 \%, 5-10 \%, 10-20 \%$ and $>20 \%)$. A regression analysis between the mean absolute errors and mean slope within each interval sought to define a rate of slope-induced error from SRTM altimetry (Gorokhovich and Voustianiouk 2006; Rexer and Hirt 2014). The SRTM C- and X- bands have limitations to reach the bare ground in the presence of a forest canopy (Walter et al. 2007). Therefore, the SRTM vertical accuracy depends on vegetation characteristics (tree height, density, branching angle, among others) (Brown et al. 2010; Pinel et al. 2015). In this research, we evaluated the type of vegetation for the points of greatest errors.

Table 2: PEC values for classes "A", "B" and "C" at 1:100,000 and 1:50,000 scales. Data source: decree no 89.817 / 84 (Chai and Draxler 2014; Santos 2010).

\begin{tabular}{c|c|c|c|c}
\hline & \multicolumn{2}{|c|}{$1: 50,000$} & \multicolumn{2}{c}{$1: 100,000$} \\
\hline & Tolerance & RMSE & Tolerance & RMSE \\
\hline A & $90 \%$ of points $<10.0 \mathrm{~m}$ & $6.6 \mathrm{~m}$ & $90 \%$ of points $<25.0 \mathrm{~m}$ & $16,6 \mathrm{~m}$ \\
\hline B & $90 \%$ of points $<12.0 \mathrm{~m}$ & $8.0 \mathrm{~m}$ & $90 \%$ of points $<30.0 \mathrm{~m}$ & $20,0 \mathrm{~m}$ \\
\hline C & $90 \%$ of points $<15.0 \mathrm{~m}$ & $10.0 \mathrm{~m}$ & $90 \%$ of points $<37.5 \mathrm{~m}$ & $25,0 \mathrm{~m}$ \\
\hline
\end{tabular}

\section{Results}

\subsection{Statistical Analysis of Errors and PEC Classification}

SRTM vertical accuracy varied considerably among the models evaluated, with a significant difference of the RMSE in the 14 ㅇ- 10 oS range between the CGIAR-CSI model $(18.43 \mathrm{~m})$ and Jonathan de Ferranti $(9.61 \mathrm{~m})$ (Table 3 ). The RMSE of HydroSHEDS (12.68 m) showed a little different to values found by Santos et al. (2006) of $11.066 \mathrm{~m}$ in the Amazon Region (between 02은 and 02N). The SRTM model, regardless of data source, did not show a constant variation in the field measurements. The Jonathan de Ferranti's model presented the lowest values of the RMSE in 7 of the 9 latitude intervals. Compared with the researches developed in South America, the result has a higher similarity with the Mukul et al., (2015) (RMSE of $11.2 \mathrm{~m}$ ). These results may have been influenced by the type of data 
used. Mukul et al., (2015) compared with field points (GCPs) like the present study.

The PEC classification considered two types of analysis: one local (Latitude bands) and another general (all Brazil) (Table 4). The models at a scale of 1:100,000 showed a PEC classification of " $A$ " predominantly in the local analysis (with few exceptions acquiring " $B$ ") and obtained " $A$ " class in general analysis. The 1: 50,000 scale models had different classifications in the local analysis (" $\mathrm{A}$ ", " $\mathrm{B}$ ", or " $\mathrm{C}$ ") and were not classifiable considering general approach (Table 4). The Jonathan de Ferranti's model presents considerably better results for models with $90 \mathrm{~m}$, with smaller errors for $90 \%$ of the points and standard deviation (Table 4).

Table 3: Summary of SRTM statistics obtained at latitude intervals. Where the models show the following numeration: 1-CGIAR-CSI; 2- EMBRAPA; 3-HydroSheds; 4- Jonathan de Ferranti; 5- SRTM-GL1.

\begin{tabular}{|c|c|c|c|c|c|c|c|c|c|c|c|}
\hline \multirow[b]{2}{*}{ Interval } & \multirow[b]{2}{*}{ Points } & \multicolumn{5}{|c|}{ Mean Error (meter) } & \multicolumn{5}{|c|}{ Standard deviation } \\
\hline & & 1 & 2 & 3 & 4 & 5 & 1 & 2 & 3 & 4 & 5 \\
\hline $02^{\circ} \mathrm{N}-06^{\circ} \mathrm{N}$ & 76 & -0.4 & -0.07 & -11.94 & -0.61 & -0.48 & 4.36 & 5.46 & 8.03 & 3.79 & 3.41 \\
\hline $02^{\circ} \mathrm{S}-02^{\circ} \mathrm{N}$ & 159 & 13.17 & 15.25 & 1.97 & 12.15 & 10.83 & 10.16 & 9.47 & 12.56 & 8.28 & 8.54 \\
\hline $06^{\circ} \mathrm{S}-02^{\circ} \mathrm{S}$ & 51 & 4.44 & 4.31 & -14.91 & 4.01 & 4.30 & 3.38 & 8.99 & 8.82 & 2.84 & 3.34 \\
\hline $10^{\circ} \mathrm{S}-06^{\circ} \mathrm{S}$ & 134 & 1.21 & 2.26 & -5.68 & 0.3 & -0.14 & 6.72 & 8.88 & 8.76 & 5.37 & 5.07 \\
\hline $14^{\circ} \mathrm{S}-10^{\circ} \mathrm{S}$ & 132 & 13.51 & 11.15 & 9.04 & 7.7 & 5.75 & 12.57 & 10.29 & 12.75 & 5.77 & 5.07 \\
\hline $18^{\circ} \mathrm{S}-14^{\circ} \mathrm{S}$ & 149 & 8.07 & 9.47 & 5.39 & 7.79 & 6.88 & 6.15 & 6.69 & 7.02 & 4.91 & 4.14 \\
\hline $22^{\circ} \mathrm{S}-18^{\circ} \mathrm{S}$ & 69 & 6.72 & 8.18 & -4.77 & 6.91 & 7.48 & 3.25 & 5.50 & 5.46 & 3.07 & 4.22 \\
\hline $26^{\circ} \mathrm{S}-22^{\circ} \mathrm{S}$ & 127 & 10.77 & 14.11 & 5.33 & 9.19 & 7.57 & 11.18 & 9.66 & 10.18 & 5.64 & 4.58 \\
\hline $30^{\circ} \mathrm{S}-26^{\circ} \mathrm{S}$ & 190 & 6.03 & 7.74 & 0.07 & 4.91 & 3.86 & 10.75 & 14.23 & 14.78 & 7.88 & 6.91 \\
\hline \multirow[t]{2}{*}{ Total (Brazil) } & 1087 & 9.78 & 8.89 & 0.24 & 6.33 & 5.35 & 8.16 & 11.20 & 12.70 & 7.22 & 6.64 \\
\hline & & \multicolumn{5}{|c|}{$\begin{array}{l}\text { Minimum error - Maximum error } \\
\text { (absolute values-meter) }\end{array}$} & \multicolumn{5}{|c|}{ Root Mean Square Error } \\
\hline Interval & Points & 1 & 2 & 3 & 4 & 5 & 1 & 2 & 3 & 4 & 5 \\
\hline $02^{\circ} \mathrm{N}-06^{\circ} \mathrm{N}$ & 76 & $\begin{array}{c}0.06 \\
15.27 \\
\end{array}$ & $\begin{array}{c}0.05 \\
16.45 \\
\end{array}$ & $\begin{array}{c}0.28 \\
34.66 \\
\end{array}$ & $\begin{array}{c}0.04 \\
14.81 \\
\end{array}$ & $\begin{array}{c}0.01 \\
11.10 \\
\end{array}$ & 4.35 & 5.42 & 14.11 & 3.82 & 3,42 \\
\hline $02^{\circ} \mathrm{S}-02^{\circ} \mathrm{N}$ & 159 & $\begin{array}{c}0.28 \\
43.62 \\
\end{array}$ & $\begin{array}{c}1.16 \\
44.51\end{array}$ & $\begin{array}{c}0.11 \\
32.64\end{array}$ & $\begin{array}{c}0.41 \\
32.77\end{array}$ & $\begin{array}{c}0.21 \\
34.45\end{array}$ & 16.62 & 17.94 & 12.68 & 14.69 & 13,78 \\
\hline $06^{\circ} \mathrm{S}-02^{\circ} \mathrm{S}$ & 51 & $\begin{array}{c}0.11 \\
12.02 \\
\end{array}$ & $\begin{array}{c}0.30 \\
35.57 \\
\end{array}$ & $\begin{array}{c}0.20 \\
34.33 \\
\end{array}$ & $\begin{array}{l}0.21 \\
9.98 \\
\end{array}$ & $\begin{array}{c}0.41 \\
14.77 \\
\end{array}$ & 5.57 & 9.89 & 17.01 & 4.90 & 5,43 \\
\hline $10^{\circ} \mathrm{S}-06^{\circ} \mathrm{S}$ & 134 & $\begin{array}{c}0.02 \\
22.47 \\
\end{array}$ & $\begin{array}{c}0.02 \\
42.64 \\
\end{array}$ & $\begin{array}{c}0.16 \\
37.68 \\
\end{array}$ & $\begin{array}{c}0.04 \\
18.84 \\
\end{array}$ & $\begin{array}{c}0.02 \\
18.22 \\
\end{array}$ & 6.80 & 9.13 & 10.42 & 5.36 & 5,04 \\
\hline $14^{\circ} \mathrm{S}-10^{\circ} \mathrm{S}$ & 132 & $\begin{array}{c}0.82 \\
54.75 \\
\end{array}$ & $\begin{array}{c}0.15 \\
71.30 \\
\end{array}$ & $\begin{array}{r}0.18 \\
49.02 \\
\end{array}$ & $\begin{array}{c}0.22 \\
23.71 \\
\end{array}$ & $\begin{array}{c}0.22 \\
19.19 \\
\end{array}$ & 18.43 & 17.53 & 15.60 & 9.61 & 7,65 \\
\hline $18^{\circ} \mathrm{S}-14^{\circ} \mathrm{S}$ & 149 & $\begin{array}{c}0.06 \\
26.02\end{array}$ & $\begin{array}{c}0.48 \\
26.57\end{array}$ & $\begin{array}{c}0.12 \\
25.28\end{array}$ & $\begin{array}{c}0.01 \\
20.74\end{array}$ & $\begin{array}{c}0.24 \\
20.96\end{array}$ & 10.13 & 11.58 & 8.83 & 9.21 & 8,02 \\
\hline $22^{\circ} \mathrm{S}-18^{\circ} \mathrm{S}$ & 69 & $\begin{array}{c}0.02 \\
13.23 \\
\end{array}$ & $\begin{array}{c}0.95 \\
19.69 \\
\end{array}$ & $\begin{array}{c}0.33 \\
15.66 \\
\end{array}$ & $\begin{array}{c}2.17 \\
15.47 \\
\end{array}$ & $\begin{array}{c}1.35 \\
17.86 \\
\end{array}$ & 7.46 & 9.84 & 7.23 & 7.55 & 8,56 \\
\hline $26^{\circ} \mathrm{S}-22^{\circ} \mathrm{S}$ & 127 & $\begin{array}{c}1.10 \\
39.79 \\
\end{array}$ & $\begin{array}{c}0.13 \\
54.43 \\
\end{array}$ & $\begin{array}{c}0.16 \\
34.16 \\
\end{array}$ & $\begin{array}{r}0.59 \\
24.52 \\
\end{array}$ & $\begin{array}{c}0.13 \\
19.44 \\
\end{array}$ & 15.49 & 17.08 & 11.45 & 10.78 & 8,84 \\
\hline $30^{\circ} \mathrm{S}-26^{\circ} \mathrm{S}$ & 190 & $\begin{array}{c}0.08 \\
49.25 \\
\end{array}$ & $\begin{array}{c}0.06 \\
76.98 \\
\end{array}$ & $\begin{array}{c}0.03 \\
63.68\end{array}$ & $\begin{array}{c}0.02 \\
36.64 \\
\end{array}$ & $\begin{array}{c}0.01 \\
27.68 \\
\end{array}$ & 12.31 & 16.16 & 14.74 & 9.27 & 7,89 \\
\hline Total (Brazil) & 1087 & $\begin{array}{c}0.02 \\
54.75\end{array}$ & $\begin{array}{c}0.02 \\
76.98\end{array}$ & $\begin{array}{c}0.03 \\
63.68\end{array}$ & $\begin{array}{c}0.01 \\
36.64\end{array}$ & $\begin{array}{c}0.01 \\
34.45\end{array}$ & 12.74 & 14.34 & 12.70 & 9.61 & 8,52 \\
\hline
\end{tabular}


Table 4: PEC Classification by latitude interval (RMSE and Tolerance of Table 2). Where the models show the following numeration: 1- CGIAR-CSI; 2-EMBRAPA; 3-HydroSheds; 4- Jonathan de Ferranti; 5- SRTM 30m of resolution. The symbol $X$ represent the model does not classify into any PEC class (Santos 2010).

\begin{tabular}{|c|c|c|c|c|c|}
\hline Interval & 1 & 2 & 3 & 4 & 5 \\
\hline & \multicolumn{5}{|c|}{$90 \%$ of the points < / PEC $1: 100,000$ / PEC 1:50,000 } \\
\hline $020 \mathrm{~N}-06 \mathrm{oN}$ & $5.81 / \mathrm{A} / \mathrm{A}$ & $9.74 / \mathrm{A} / \mathrm{A}$ & $21.65 / \mathrm{A} / \mathrm{X}$ & $5.29 / \mathrm{A} / \mathrm{A}$ & $5.16 / \mathrm{A} / \mathrm{A}$ \\
\hline $020 \mathrm{OS}-02 \mathrm{oN}$ & $24.38 / \mathrm{A} / \mathrm{X}$ & $27.16 / \mathrm{B} / \mathrm{X}$ & $18.5 / \mathrm{A} / \mathrm{X}$ & $21.44 / \mathrm{A} / \mathrm{X}$ & $21.69 / \mathrm{A} / \mathrm{X}$ \\
\hline $060 \mathrm{OS}-02 \mathrm{oS}$ & $7.99 / \mathrm{A} / \mathrm{A}$ & $11.1 / \mathrm{A} / \mathrm{C}$ & $23.3 / B / X$ & $7.52 / \mathrm{A} / \mathrm{A}$ & $7.88 / \mathrm{A} / \mathrm{A}$ \\
\hline $10 \mathrm{os}-06 \mathrm{os}$ & $12.52 / \mathrm{A} / \mathrm{C}$ & $13.84 / \mathrm{A} / \mathrm{C}$ & $16.59 / \mathrm{A} / \mathrm{X}$ & $9.26 / \mathrm{A} / \mathrm{A}$ & $7.90 / \mathrm{A} / \mathrm{A}$ \\
\hline $140 S-10 o S$ & $29.01 / B / X$ & $26.19 / \mathrm{B} / \mathrm{X}$ & $24.26 / \mathrm{A} / \mathrm{X}$ & $14.13 / \mathrm{A} / \mathrm{C}$ & $11.79 \mathrm{~A} / \mathrm{B}$ \\
\hline $180 \mathrm{o}-14 \mathrm{oS}$ & $15.77 / \mathrm{A} / \mathrm{X}$ & $19.07 / \mathrm{A} / \mathrm{X}$ & $13.12 / \mathrm{A} / \mathrm{C}$ & $14.33 / \mathrm{A} / \mathrm{C}$ & $12.11 / \mathrm{A} / \mathrm{C}$ \\
\hline $220 S-180 S$ & $10.47 / \mathrm{A} / \mathrm{B}$ & $14.43 / \mathrm{A} / \mathrm{C}$ & $9.86 / \mathrm{A} / \mathrm{B}$ & $10.83 / \mathrm{A} / \mathrm{B}$ & $12,49 / \mathrm{A} / \mathrm{C}$ \\
\hline $260 S-220 \mathrm{~s}$ & $23.78 / \mathrm{A} / \mathrm{X}$ & $26.85 / \mathrm{B} / \mathrm{X}$ & $16.66 / \mathrm{A} / \mathrm{X}$ & $15.8 / \mathrm{A} / \mathrm{X}$ & $13.41 / \mathrm{A} / \mathrm{C}$ \\
\hline $30 \circ \mathrm{os}-26 \mathrm{os}$ & $17.59 / \mathrm{A} / \mathrm{X}$ & $25.68 / \mathrm{B} / \mathrm{X}$ & $23.94 / \mathrm{A} / \mathrm{X}$ & $14.4 / \mathrm{A} / \mathrm{C}$ & $11.27 / \mathrm{A} / \mathrm{B}$ \\
\hline Total & $19.71 / \mathrm{A} / \mathrm{X}$ & $22.55 / \mathrm{A} / \mathrm{X}$ & $20.36 / \mathrm{A} / \mathrm{X}$ & $15.52 / \mathrm{A} / \mathrm{X}$ & $14.19 / \mathrm{A} / \mathrm{C}$ \\
\hline
\end{tabular}

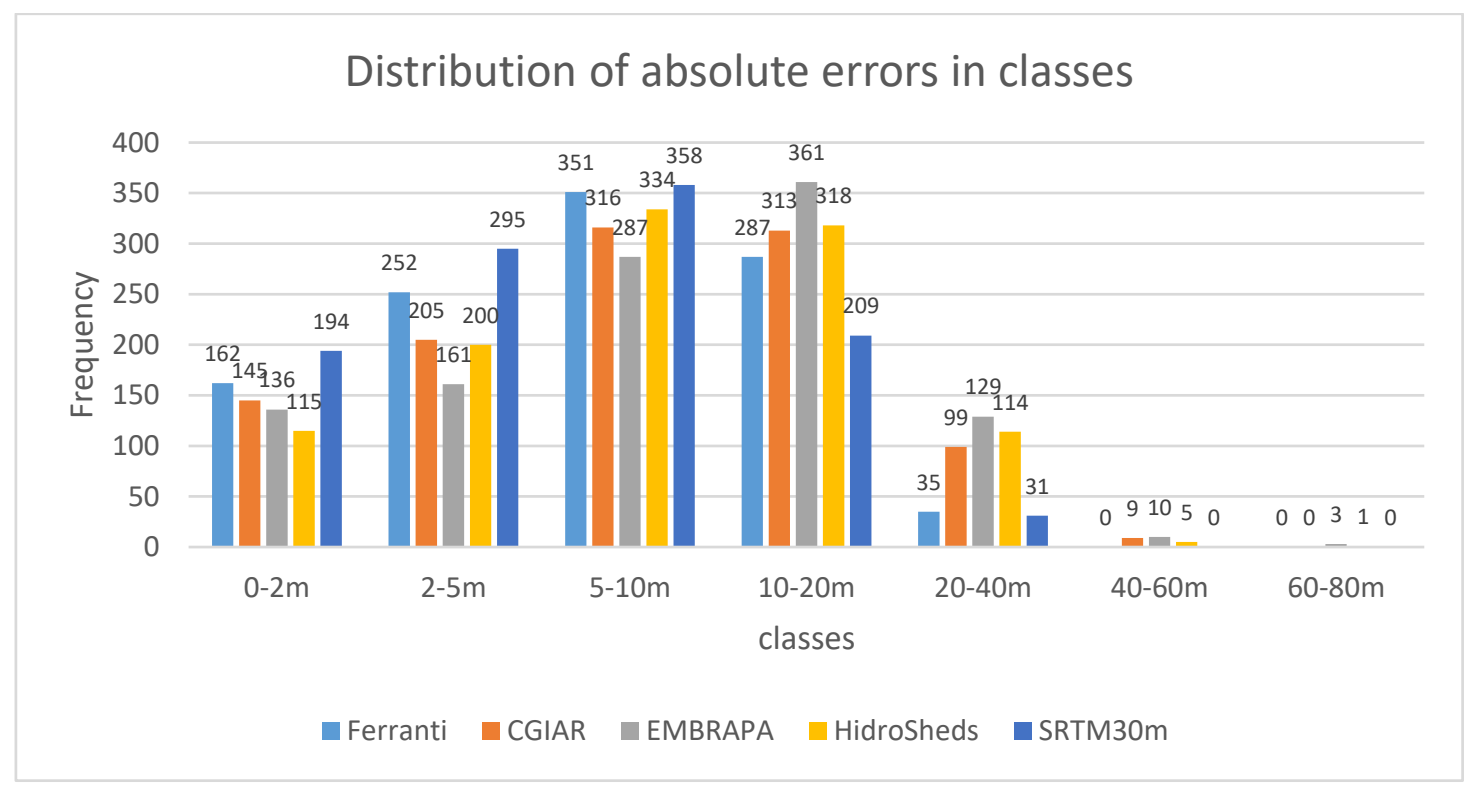

Figure 3: Histogram of distribution of absolute errors in classes.

Predictably, the 30-meter resolution model showed higher accuracy than the 90-meter resolution models. However, although the resolution is three times better, the accuracy is approximately $10 \%$ higher. For example, the RMSE of Jonathan de Ferranti's model for all Brazil is of $9.61 \mathrm{~m}$, while for the SRTM-GL1 is of $8.52 \mathrm{~m}$. The obtained RMSE result for SRTM GL1 was compatible with that found for the South American Andean Plateau (RMSE = 9.7) (Satge et al. 2016).

\subsection{Analysis of Slope and Vegetation in the Altimetric Accuracy}

In the slope analyzes, we used only the 90-meter resolution model with the best accuracy (Jonathan de 
Ferranti's SRTM). The absolute values of the average error varied linearly with the mean slope within each slope range, obtaining a significant coefficient of determination (R2) of 0,907 (Figure 4). Complementarily, the secondorder polynomial function obtains an extremely accurate adjustment of the data, achieving an R2 of 0.999 . The average magnitude of errors in slope terrains $(>20 \%)$ is approximately twice higher than flat terrain $(<1 \%)$. The regression obtained serves as a basis to estimate the expected errors in the different types of relief. The results were consistent with other surveys, which demonstrated that the highest errors occur preferentially in mountainous regions than in flat areas (Sun et al. 2003; Gorokhovich and Voustianiouk 2006; Rexer and Hirt 2014).

Shortridge and Messina (2011) emphasize the importance of evaluating vegetation interference in the most significant errors found in SRTM altimetry. In the present study, the highest errors within each analyzed latitude zone occurred in densely vegetated areas (Figure 5). Thus, this simple qualitative analysis evidenced the vegetation influence on the SRTM model accuracy. This expected behavior is because the SRTM is a digital surface model (MDS) and not originally a digital terrain model (MDT). The electromagnetic waves of the $\mathrm{C}$ - and X- radar bands interact with elements larger than their respective wavelengths such as dense vegetation, causing significant altimetric differences in SRTM data (Sun et al. 2003; Brochado 2015; Pinel et al. 2015). The present study did not evaluate in depth the role of vegetation in the altimetric errors, not considering in detail the type of canopy and height of the trees. However, the research showed that vegetation interference was the main source of error encountered, confirming the results of other surveys (Ludwig and Schneider 2006; Pinel et al. 2015).

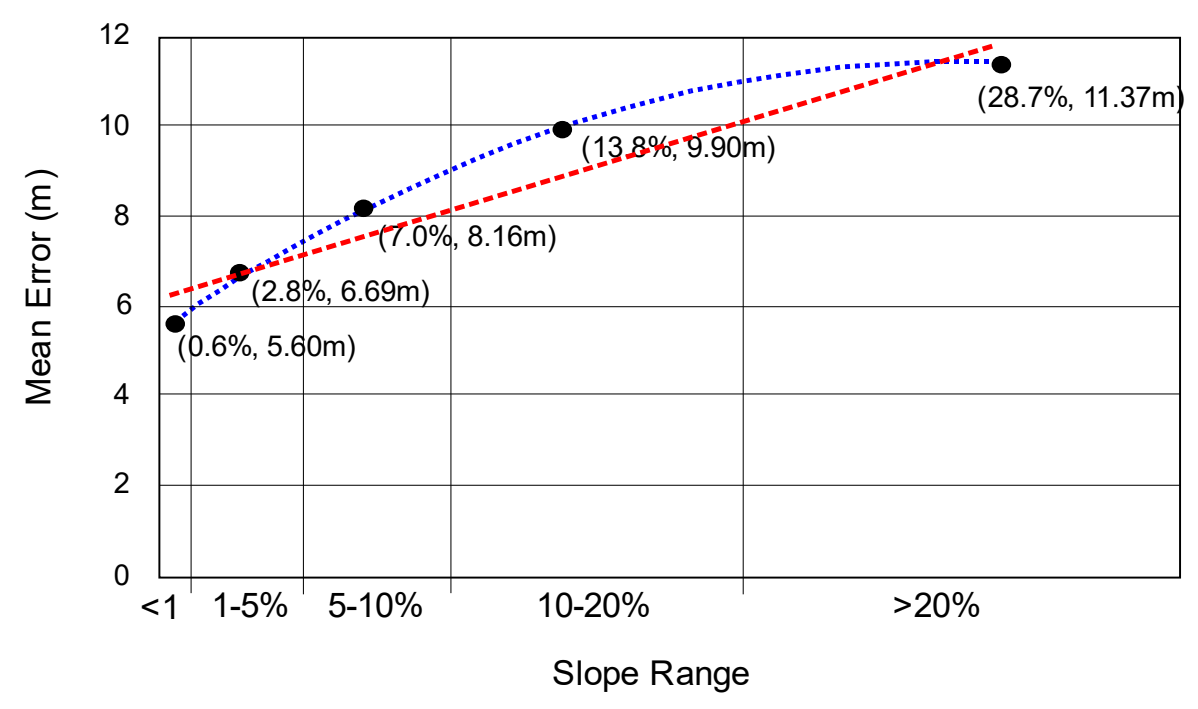

Figure 4: Regression functions between the Mean Absolute Error (MAE) of the Jonathan de Ferranti's SRTM and mean slope within each slope ranges $(<1 \%, 1-5 \%, 5-10 \%, 10-20 \%$, and $>20)$. Red line is the linear best fit line $(y=$ $0.1965 x+6.2603$ ) with the coefficient of determination $\left(R^{2}\right)$ of 0.907 , while the blue line is the polynomial best fit line $\left(y=-0.0081 x^{2}+0.4397 x+5.4284\right)$ with $R^{2}$ of 0.999 . 

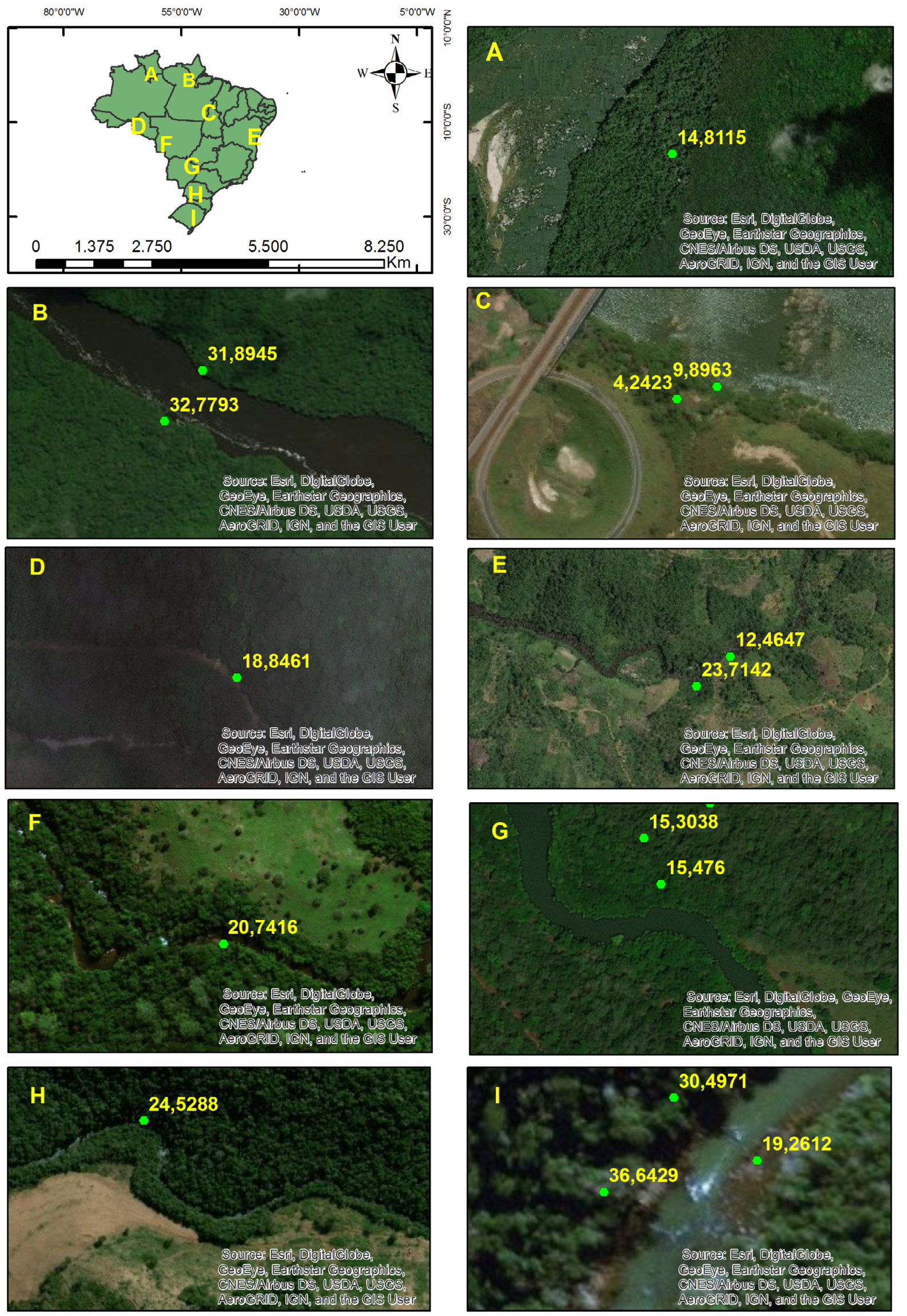

Figure 5. Position of the largest errors by latitude range from Jonathan de Ferranti's SRTM and its incidence in forested regions. Image Source: Esri, DigitalGlobe, GeoEye, Earthstar Geographicas, CNES / Airbus DS, USDA, USGS, AEX, Getmapping, Aerogrid, IGN, IGP, Swisstopo, the GISUser Community. 


\section{Conclusion}

The results show a variation of the vertical accuracy within the Brazilian territory according to SRTM type: EMBRAPA (RMSE of $14.74 \mathrm{~m}$ ); HydroSHEDS (RMSE of $12.70 \mathrm{~m}$ ); CGIAR-CSI (RMSE of $12.74 \mathrm{~m}$ ); Jonathan de Ferranti (RMSE of $9.61 \mathrm{~m}$ ); and SRTM-GL1 (RMSE of $8.52 \mathrm{~m}$ ). Therefore, several SRTM models demonstrate significant differences, whereas Jonathan de Ferranti's model presents the most consistent behavior and the best altimetry accuracy for the 90-meter resolution models. The classification of models corresponds to "PEC-A" at 1:100,000 scale for all 1087 points. The SRTM-GL1 model with a resolution of 30 meters provided an improvement in the altimetric accuracy by approximately $10 \%$, reaching the PEC " $C$ " at 1: 50,000 scale for the total data set evaluated in research. However, Jonathan de Ferranti's model is not much more imprecise than SRTM-GL1. The SRTM height bias has a direct correlation with the slope, having a perfect fit with the second-order polynomial function $(R 2=0.99)$. The highest errors occur in forested areas.

\section{ACKNOWLEDGMENT}

The authors are grateful for the financial support of Coordenação de Aperfeiçoamento de Pessoal de Nível Superior (CAPES) and Conselho Nacional de Desenvolvimento Científico e Tecnológico (CNPq).

\section{AUTHOR'S CONTRIBUTION}

Alex Gois Orlandi, Osmar Abílio de Carvalho Júnior and Renato Fontes Guimarães wrote the manuscript and was responsible for the research design, mathematical model, data preparation, and analysis. Alex Gois Orlandi and Douglas Corbari Corrêa provided some of the data, conducted the field-works, and gave technical support. Edilson de Souza Bias and Roberto Arnaldo Trancoso Gomes provided significant input to the numerical analysis. All the authors contributed to the editing and reviewing of the manuscript.

\section{REFERENCES}

Agência Nacional de Energia Elétrica (ANEEL). 2009. Diretrizes para elaboração de serviços de cartografia $e$ topografia relativos a aproveitamentos hidrelétricos. [pdf] Brasília: ANEEL. Retrieved from: <http://www2.aneel. gov.br/scg/Doc/Diretrizes_Topografia.pdf> [Accessed 25 August 2017].

Athmania, D., Achour, H. 2014. External validation of the ASTER GDEM2, GMTED2010 and CGIAR-CSI- SRTM v4.1 free access Digital Elevation Models (DEMs) in Tunisia and Algeria. Remote Sensing, 6, p.4600-4620.

Azizian, A., Shokoohi, A. Effects of data resolution and stream delineation threshold area on the results of a kinematic wave based GIUH model. Water, 41(1), p.61-70, 2015.

Berry, P. A. M., Garlick, J. D.; Smith, R. G. 2007. Near-global validation of the SRTM DEM using satellite radar altimetry. Remote Sensing of Environment, 106, p.17-27.

Bias, S. E., Ribeiro, C. J. R., Baptista, M. M. G., Bernardi, E. V. J. 2010. Avaliação da exatidão do MDE obtido por meio do SRTM e pela carta do IBGE na escala 1:100.000. Revista Brasileira de Cartografia, 63(01), p.149-155. 
Brasil 1984. Decreto no 89.817 de 20 de julho de 1984. Estabelece as instruções reguladoras das Normas Técnicas da Cartografia Nacional. Retrieved from: <http://www.planalto.gov.br/ccivil_03/decreto/1980-1989/D89817.htm> [Accessed 25 August 2017].

Brochado, G.T. 2015. Atenuação do efeito do desflorestamento em dados SRTM por meio de deferentes técnicas de interpolação. 113p. Dissertação (Mestrado em Sensoriamento Remoto) Instituto de Pesquisas Espaciais, São José dos Campos, São Paulo. Retrieved from: <http://urlib.net/8JMKD3MGP3W34P/3HT5JCL>. [Accessed 25 August 2017].

Brown, G., Sarabandi, K., Pierce, L. 2010. Model-based estimation of forest canopy height in red and austrian pine stands using shuttle radar topography mission and ancillary data: A proof-of-concept study. IEEE Transactions on Geoscience and Remote Sensing. 48, p.1105-1118.

Chai, T., Draxler, R.R., 2014. Root mean square error (RMSE) or mean absolute error (MAE)? - Arguments against avoiding RMSE in the literature. Geoscientific Model Development, 7, p.1247-1250.

Chaieb, A., Rebai, N., Bouaziz, S. 2016. Vertical accuracy assessment of SRTM Ver 4.1 and ASTER GDEM Ver 2 using GPS measurements in Central West of Tunisia. Journal of Geographic Information System, 8, p.57-64.

Consultative Group for International Agricultural Research-Consortium for Spatial Information (CGIAR-CSI). 2016. Retrieved from: <http://www.cgiar-csi.org/data/srtm-90m-digital-elevation-database-v4-1> [Accessed 25 August 2017].

Dasgupta, S., Laplante, B., Murray, S., Wheeler, D. 2011. Exposure of developing countries to sea-level rise and storm surges. Climatic Change, 106, p.567-579.

Datta, P. S., Kirchner, H. S. 2010. Erosion relevant topographical parameters derived from different DEMs-A comparative study from the Indian Lesser Himalayas. Remote Sensing, 2, p.1941-1961.

de Carvalho Júnior, O. A., Guimarães, R. F., Montgomery, D. R., Gillespie, A. R., Trancoso Gomes, R. A., de Souza Martins, E., Silva, N. C. 2014. Karst depression detection using ASTER, ALOS/PRISM and SRTM-derived digital elevation models in the Bambuí Group, Brazil. Remote Sensing, 6, 330-351.

Fernandes, M., Menezes, P. M. L. 2005. Avaliação de métodos de geração de MDE para a obtenção de observações em superfície real: um estudo de caso no maciço da Tijuca-RJ. In: XII Simpósio Brasileiro do Sensoriamento Remoto, Goiânia, Brasil. INPE, p.2985-2992.

Ferranti, J. 2016. Digital Elevation Data. Retrieved from: <http://www.viewfinderpanoramas.org/dem3.html>. [Accessed 25 August 2017]

Frey, H., Paul, F. 2012. On the suitability of the SRTM DEM and ASTER GDEM for the compilation of topographic parameters in glacier inventories. International Journal of Applied Earth Observation and Geoinformation, 18, p.480-490.

Gorokhovich, A., Voustianiouk, A. 2006. Accuracy assessment of the processed SRTM-based elevation data by CGIAR using field data from USA and Thailand and its relation to the terrain characteristics. Remote Sensing of Environment, 104, p.409-415.

Iorio, M. M., Lastoria, G., Mioto, C. L., Albrez, A., Filho, P. C. A. 2012. Avaliação de Modelos Digitais de Elevação extraídos de imagem ALOS/PRISM e comparação com os modelos disponibilizados gratuitamente na WEB. Geociências, 31(4), p. 650-664.

Jarihani, A. A., Callow, J. N., Mcvicar, T. R., Nile, T. G. V., Larsen, J. R. 2015. Satellite-derived Digital Elevation Model (DEM) selection, preparation, and correction for hydrodynamic modelling in large, low-gradient and data-sparse catchments. Journal of Hydrology, 524, p.489-506.

Karwel, A. K., Ewiak, I. 2008. Estimation of the Accuracy of the SRTM Terrain Modelo on the Area of Poland. In: The International Archives of the Photogrammetry, Remote Sensing and Spatial Information Sciences. Vol. XXI, Part B7, Beijing, p.169-172.

Kolecka, N., Kozak, J. 2014. Assessment of the accuracy of SRTM C- and X-band high mountain elevation data: A case study of the Polish Tatra Mountains. Pure and Applied Geophysics, 171, p.897-912. 
Lehner, B. 2012. Derivation of watershed boundaries for GRDC gauging stations based on the HydroSHEDS drainage network. Global Runoff Data Centre (GRDC). Technical Report 41.

Lehner, B., Verdin, K., Jarvis, A. 2006. HydroSHEDS Technical Documentation. World Wildlife Fund US, Washington, DC, 2006. Retrieved from: <http://hydrosheds.cr.usgs.gov> [Accessed 25 December2017]

Liu, Y. 2008. An Evaluation on the Data Quality of SRTM DEM at the Alpine and Plateau Area, North-Western of China. In: The International Archives of the Photogrammetry, Remote Sensing and Spatial Information Sciences. Vol. XXXVII, Part B1, Beijing. p.1123-1128.

Ludwig, R., Schneider, P. 2006. Validation of digital elevation models from SRTM XSAR for applications in hydrologic modeling. ISPRS Journal of Photogrammetry \& Remote Sensing 60, p.339-358.

Medeiros, C. L., Ferreira, C. N., Ferrreira, G. L. 2009.Avaliação de modelos digitais de elevação para delimitação automática de bacias hidrográficas. Revista Brasileira de Cartografia, 61(02), p.137-151.

Miceli, S. B., Dias, M. F., Seabra, M. F., Santos, A. R. P., Fernandes, C. M. 2011. Avaliação vertical de Modelos Digitais de Elevação (MDEs) em diferentes configurações topográficas para médias e pequenas escalas. Revista Brasileira de Cartografia, 63(01), p.191-201.

Miranda, E. E. de; (Coord.). 2015. Brasil em Relevo. Campinas: Embrapa Monitoramento por Satélite, 2005. Retrieved from: <http://www.relevobr.cnpm.embrapa.br> [Accessed 22 January 2018].

Moura, L. Z., Bias, E. S., Brites, R. 2014. Avaliação da acurácia vertical de Modelos Digitais de Elevação (MDES) nas bacias do Paranoá e São Bartolomeu. Revista Brasileira de Cartografia, 66(01), p.1-14.

Mukherjee, S., Joshi, P. K., Mukherjee, S., Ghosi, A., Garc, R. D., Mukhopadhyay, A. 2013. Evaluation of vertical accuracy of open source Digital Elevation Model (DEM). International Journal of Applied Earth Observation and Geoinformation, 21, p.205-217.

Mukul, M., Srivastava, V., Mukul, M. 2015. Analysis of the accuracy of Shuttle Radar Topography Mission (SRTM) height models using International Global Navigation Satellite System Service (IGS) Network. Journal of Earth System Science, 124, p.1343-135721.

NASA JPL (2013). NASA Shuttle Radar Topography Mission Global 1 arc second [Data set]. NASA EOSDIS Land Processes DAAC. doi: 10.5067/MEaSUREs/SRTM/SRTMGL1.003.

Nobrega, A. A. R., Santos, C., Cintra, P. J. 2005. Comparação Quantitativa e Qualitativa entre o Modelo Digital Gerado pelo SRTM e por Aerofotogrametria. Anais XII Simpósio Brasileiro de Sensoriamento Remoto, Goiânia, Brasil, INPE, p. 4437-4444.

Ouerghi, S., Elsheikh, R. F. A., Achour, H., Bouazi, S. 2015. Evaluation and validation of recent freely-available ASTERGDEM V.2, SRTM V.4.1 and the DEM Derived from topographical map over SW Grombalia (Test Area) in North East of Tunisia. Journal of Geographic Information System, 7, pp.266-279.

Pinel, S., Bonnet, M. P., Santos Da Silva, J., Moreira, D., Calmant, S., Satgé, F., Seyler, F., Schumann, J.-P.G., Koch, M., Thenkabail, P.S. 2015. Correction of interferometric and vegetation biases in the SRTMGL1 spaceborne DEM with hydrological conditioning towards improved hydrodynamics modeling in the amazon basin. Remote Sensing, 7, p.16108-16130.

Reuter, H. I., Nelson, A., Jarvis, A. 2007. An evaluation of void-filling interpolation methods for SRTM data. International Journal of Geographical Information Science, 21(9), p.983-1008.

Rexer, M., Hirt, C. 2014. Comparison of free high-resolution digital elevation data sets (ASTER GDEM2, SRTM v2.1/ v4.1) and validation against accurate heights from the Australian National Gravity Database. Australian Journal of Earth Sciences, 61(2), p.213-226.

Robinson, N., Regetz, J., Guralnick, R.P. 2014. EarthEnv-DEM90: A nearly-global, void-free, multi-scale smoothed, $90 \mathrm{~m}$ digital elevation model from fused ASTER and SRTM data. ISPRS Journal of Photogrammetry and Remote Sensing, 87, p.57-67. 
Santos, A. P. 2010. Avaliação da acurácia posicional em dados espaciais com o uso da estatística espacial. 110p. Dissertação (Mestrado em Engenharia Civil) Universidade Federal de Viçosa, Viçosa, Minas Gerais. Disponível em: < http://www.locus.ufv.br/handle/123456789/3733 >. [Acesso em agosto de 2017].

Santos, A. R. P., Gaboardi, C., Oliveira, C. L. 2006. Avaliação da precisão vertical dos modelos SRTM para a Amazônia. Revista Brasileira de Cartografia, 58(01), p.101-107.

Satge, F., Denezine, M., Pillco, R., Timouk, F., Pinel, S., Molina, J., Garnier, J., Seyler, F., Bonnet, M.P. 2016. Absolute and relative height-pixel accuracy of SRTM-GL1 over the South American Andean Plateau. ISPRS Journal of Photogrammetry and Remote Sensing, 121, p.157-166.

Sena-Souza, J. P., de Carvalho Júnior, O. A., Martins, E. S.; Vasconcelos, V., Couto Júnior, A. F., Gomes, R. A. T., Guimarães, R. F. 2016. Comparação dos métodos de classificação por ângulo espectral e distância euclidiana no mapeamento das formas de terreno. Revista Brasileira de Geomorfologia, 17, p.591-613.

Shortridge, A., Messina, J. 2011. Near-global validation of the SRTM DEM using satellite radar altimetry. Remote Sensing of Environment, 115, p.1576-1587.

Siart, C.; Bubenzer, O., Eitel, B. 2009. Combining digital elevation data (SRTM/ASTER), high resolution satellite imagery (Quickbird) and GIS for geomorphological mapping: A multi-component case study on Mediterranean karst in Central Crete. Geomorphology, 112, p.106-121.

Sun, G., Ranson, K.J., Kharuk, V.I., Kovacs, K. 2003. Validation of surface height from shuttle radar topography mission using shuttle laser altimeter. Remote Sensing of Environment, 88, p.401-411.

Suwandana, E., Kawamura, K., Sakuno, Y., Kustianto, E., Raharjo, B. 2012. Evaluation of ASTER GDEM2 in Comparison with GDEM1, SRTM DEM and Topographic-Map-Derived DEM Using Inundation Area Analysis and RTK-DGPS Data. Remote Sensing, 4, p.2419-2431.

Tait, A. 2010. Some useful Digital Elevation Datasets. Cartographic Perspectives, 67, p.63-74.

Tarquini, S., Vinci, S., Favalli, M., Doumaz, F., Fornaciai, A., Nannipieri, L. 2012. Release ofa10-m-resolution DEM for the Italian territory: Comparison with global-coverage DEMs and anaglyph-mode exploration via the web. Computers \& Geosciences, 38, p.409-415.

Valeriano, M. M. 2008. Topodata: guia para utilização de dados geomorfológicos locais. São José dos Campos: INPE. Vasconcelos, V., Carvalho Junior, O. A., Martins, E. S., Couto Júnior, A. F., Guimaraes, R. F., Gomes, R. A. T. 2012. Sistema de classificação geomorfométrica baseado em uma arquitetura sequencial em duas etapas: árvore de decisão e classificador espectral, no parque nacional Serra da Canastra. Revista Brasileira de Geomorfologia, 13, p.171-186.

Walker, W., Kellndorfer, J.M., Pierce, L. 2007. Quality assessment of SRTM C- and X-band interferometric data: Implications for the retrieval of vegetation canopy height. Remote Sensing of Environment, 106, p.428-448.

Wang, W., Yang, X., Yao, T. 2012.Evaluation of ASTER GDEM and SRTM and their suitability in hydraulic modelling of a glacial lake outburst flood in southeast Tibets. Hydrological Processes, 26, p.213-225.

Watkins, D. (2018). 30-Meter SRTM Tile Downloader. Retrieved from: http://dwtkns.com/srtm30m/. 